\title{
Identifikasi Mikroorganisme Rizosfer Tanaman Rambutan (Nephelium lappaceum) di Kabupaten Kutai Kartanegara, Kalimantan Timur
}

\section{Identification of Microorganism from Rhizhosphere Rambutan Plant (Nephelium lappaceum) in Kutai Kartanegara Distric, East Kalimantan}

\author{
Purwati $^{1}$, Tutik Nugrahini ${ }^{1}$ \\ ${ }^{1}$ Tenaga Pendidik Program Studi Agroteknologi, Fakultas Pertanian, Universitas Widya Gama Mahakam \\ Jl. KH. Wahid Hasyim, Sempaja, Samarinda, Kalimantan Timur, Indonesia \\ email : purwatiuwgm@gmail.com, tutiknugrahini@uwgm.ac.id
}

Diterima : 24 Agustus 2017 Disetujui : 13 Oktober 2017

\begin{abstract}
One of the obstacles in increasing and stabilizing crop production is the onslaught of soil pathogens that causes damage to plants and decreases the quantity and quality of production. This study aims to identify and determine the population of rhizosphere microorganisms in rambutan plants. The research was conducted at Plant Pest and Disease Laboratory of Agricultural Faculty of Mulawarman University of Samarinda from July to August 2016. This research uses exploration method with observation technique which is done by growing microorganism in media so that for 5 days then calculate growth rate of each microorganism. The data obtained were analyzed using quantitative descriptive analysis. Based on the result of the research, it can be concluded that the results of isolation of micorganism from rhizosphere rambutan plant obtained 3 isolates include: 1 isolate bacteria from Azotobacteraceae Family and 2 isolates of fungi from genus Aspergilus and Phytium genus. Of the 3 types of isolates, 2 types of microorganisms are included into microorganisms that are beneficial to soil ecosystems that include the Azotobacteraceae Family that play a role in the fixation (fixation) $\mathrm{N}_{2}$ (biofertilizer) and Aspergillus Genus that act as a potential pathogen growth inhibitor (bio control) diseases in plants while the Phytium Genus is a pathogenic fungus (the cause of disease) that can affect the low production of plants.
\end{abstract}

Key words: Identification, Microorganism, Rhizosphere, Rambutan

\section{PENDAHULUAN}

Rambutan (Nephelium lappaceum) merupakan salah satu jenis buah tropis yang layak dirancang sebagai komoditas unggulan pertanian. Peluang pemasaran buah rambutan cenderung terus meningkat dari tahun ke tahun, baik di pasar domestik (dalam negeri) maupun pasar internasional. Tanaman rambutan dibudidayakan untuk dimanfaatkan buahnya yang mempunyai gizi, zat tepung, sejenis gula yang mudah terlarut dalam air, zat protein dan asam amino, zat lemak, zat enzim-enzim yang esensial dan nonesensial, vitamin dan zat mineral makro, mikro yang menyehatkan keluarga, tetapi ada pula sementara masyarakat yang memanfaatkan sebagai pohon pelindung di pekarangan, sebagai tanaman hias.

Kendala yang dihadapi pada budidaya rambutan adalah mudah terserang penyakit pada bagian daun dan batang, terutama bila suhunya lembap dan daerahnya sering terkena kabut pada pagi dan sore. Jamur rhizosfer merupakan salah satu kelompok mikrobia yang telah dilaporkan dapat menginduksi ketahanan tanaman terhadap berbagai penyakit, baik penyakit terbawa tanah maupun penyakit terbawa udara (Hyakumachi \& Kubota, 2003). Banyak jenis jamur dapat diisolasi dari rhizosfer tanaman budidaya karena jamur ini dapat memacu pertumbuhan tanaman sehingga termasuk dalam kelompok Plant Growth Promoting Fungi/ PGPF (Hyakumachi \& Kubota, 2003).

Beberapa isolat PGPF yang berasal dari Zoysiagrass (Zoysia tenuifolia), selain dapat memacu pertumbuhan tanaman juga dapat menginduksi ketahanan tanaman terhadap penyakit antraknosa pada mentimun, yang disebabkan Colletotrichum arbiculare (Meera et al., 1994). Beberapa isolat jamur rhizosfer alang-alang yang diinokulasikan pada perakaran tanaman tomat yang telah dilaporkan dapat meningkatkan ketahanan tanaman tomat terhadap penyakit bercak coklat (Alternaria solani) pada daun tanaman tomat (Hersanti, 2002). Jamur rhizosfer membantu pertumbuhan tanaman melalui berbagai mekanisme seperti peningkatan penyerapan nutrisi, sebagai kontrol biologi terhadap serangan patogen, dan juga menghasilkan hormon pertumbuhan bagi tanaman (Chanway, 1997).

Dalam hal penyediaan dan penyerapan unsur hara bagi tanaman, aktivitas mikroba diperlukan untuk menjaga ketersediaan tiga unsur hara yang 
penting bagi tanaman antara lain, nitrogen $(\mathrm{N})$, fosfat (P), dan kalium (K). Kurang lebih $80 \%$ kandungan udara adalah $\mathrm{N}$. Namun, $\mathrm{N}$ di udara tersebut harus ditambat oleh mikroba dan diubah bentuknya terlebih dahulu agar bisa langsung dimanfaatkan oleh tanaman untuk pertumbuhannya (Kristian Metasari, 2011).

Sebagian besar nitrogen yang terdapat dalam tanaman berasal dari penambatan mikroorganisme prokariot (bakteri) (Salisbury dan Ross, 1992). Penambatan nitrogen di dalam tanah dilakukan oleh jasad renik yang hidup bebas. Ada beberapa genera bakteri yang hidup dalam tanah (misalnya Azotobacter,Clostridium, dan Rhodospirillum ) yang mampu mengikat molekul-molekul nitrogen guna dijadikan senyawa-senyawa pembentuk tubuh mereka, misalnya protein (Dwijoseputro, 2005). Mikroba penambat $\mathrm{N}$ ada yang hidup bebas dan ada pula yang bersimbiosis. Mikroba penambat $\mathrm{N}$ yang simbiosis antara lain adalah Rhizobium $s p$. yang hidup di dalam bintil akar tanaman kacangkacangan (leguminose). Mikroba penambat $\mathrm{N}$ nonsimbiosis misalnya: Azospirillum sp. dan Azotobacter sp. (Kristian Metasari, 2011). Menurut Sari (2010) nitrogen memiliki fungsi bagi tanaman untuk meningkatkan pertumbuhan tanaman, menunjang pertumbuhan daun, meningkatkan kadar protein dalam tubuh tanaman, dapat meningkatkan kualitas tanaman, dan daun tanaman menjadi lebar dengan warna yang lebih hijau, kekurangan $\mathrm{N}$ menyebabkan khlorosis (pada daun muda berwarna kuning).

Jamur yang menempati rhizosfir tanaman dan menumpang pada tanaman sebagai simbion dikenal sebagai jamur endomikoriza dan ektomikoriza. Hampir setiap jenis tanaman memiliki jamur endofit yang jenisnya berbeda-beda, sehingga terdapat rentang keanekaragaman hayati yang tinggi

\section{BAHAN DAN METODE}

Penelitian dilaksanakan pada bulan Juli sampai Agustus 2016. Penelitian ini dilaksanakan di Laboratorium Hama dan Penyakit, Fakultas Pertanian, Universitas Mulawarman Samarinda. Sampel tanah diambil dari rhizosfer tanaman rambutan di lahan perkebunan masyarakat di Desa Badak Mekar Kecamatan Muara Badak Kabupaten Kutai Kartanegara, Kalimantan Timur. Bahan yang digunakan dalam penelitian ini adalah tanah dari rizosfer tanaman rambutan, Alkohol 70\%,
(Anindyawati, 2003). Jamur endofit umumnya bersimbiosis mutualisme dengan tanaman inangnya. Jamur ini memberi manfaat kepada tanaman inang antara lain berupa peningkatan laju pertumbuhan, ketahanan terhadap serangan hama, penyakit dan kekeringan. Di antara spesies-spesies jamur tanah, ada yang menguntungkan tanaman dan ada yang berperan sebagai penyakit tanaman (Tanaka, et.al, 1999).

Untuk mengetahui jenis jamur pada rhizosfer tanaman hortikultura tersebut perlu dilakukan isolasi dan identifikasi. Identifikasi merupakan suatu kegiatan yang sangat penting mengingat banyak jenis jamur belum diketahui jumlah dan jenisnya (Rifai, 1995). Penggunaan agen hayati sebagai pengendali penyakit tanaman merupakan alternatif yang sangat menjanjikan dalam mengurangi dampak negatif dari penggunaan pestisida kimia, diantaranya yaitu penggunaan pestisida secara terus menerus dan tidak terkontrol akan menyebabkan dampak negatif bagi lingkungan, seperti munculnya ketahanan patogen terhadap pestisida sintetis, timbulnya resurgensi hama dan terendapnya residu pestisida yang dapat merusak struktur tanah. Salah satu syarat suatu organisme bisa dikatakan sebagai agen hayati adalah mempunyai kemampuan antagonisme yaitu kemampuan menghambat perkembangan atau pertumbuhan organisme lainnya (Cook and Baker 1989).

Berdasarkan hal tersebut di atas, perlu dilakukan identifikasi mikroorganisme rhizosfer indigenous pada tanaman lai dan rambutan di Kabupaten Kutai Kartanegara yang dapat dimanfaatkan sebagai pupuk hayati (biofertilizer) dan anti pathogen (bio kontrol) dalam mengendalikan penyakit tanaman rambutan.

$\mathrm{NaOCl}$ 5\%, media Potato Dextrose Agar (PDA), spirtus, dan aquades steril. Penelitian ini menggunakan metode eksplorasi dengan teknik observasi yang dilakukan dengan cara menumbuhkan mikroorganisme dalam media agar selama 5 hari kemudian menghitung laju pertumbuhan tiap mikroorganisme dengan prosedur penelitian ; pengambilan sampel tanah rhizofer, isolasi mikroorganisme rhizofer, identifikasi mikroorganisme rhizofer. Data yang diperoleh dianalisis menggunakan analisis deskriptif kuantitatif. 


\section{HASIL DAN PEMBAHASAN}

\section{Morfologi Mikroorganisme Rizosfer Tanaman Rambutan}

Hasil isolasi tanah rizosfer tanaman rambutan di Kabupaten Kutai Kartanegara terdiri dari 2 famili bakteri meliputi Azotobacteracea dan baciliaceae dan 2 genus jamur meliputi Aspergilus sp. dan Phytium sp. Sampel tanah dari rizosfer tanaman rambutan menunjukkan bahwa populasi mikroba tertinggi adalah jamur meliputi $49 \times 10^{5} \mathrm{~g}^{-1}$ tanah) (Tabel 1 dan Tabel 2).

Tabel 1. Populasi bakteri pada rizosfer tanaman rambutan di Kabupaten Kutai Kartanegara

\begin{tabular}{|c|l|c|}
\hline Famili & \multicolumn{1}{|c|}{ Morfologi } & Koloni \\
\hline Azotobacteracea & $\begin{array}{l}\text { Koloni krem, tipis tebal, bergerigi } \\
\text { kokus, gram - }\end{array}$ & \\
\hline Bacillaceae & $\begin{array}{l}\text { Koloni krem, agak tebal, bergerigi, } \\
\text { gram }+\end{array}$ & \\
\hline
\end{tabular}

Tabel 2. Populasi jamur pada rizosfer tanaman rambutan di Kabupaten Kutai Kartanegara

\begin{tabular}{|c|c|c|}
\hline Spesies & Jumlah populasi & Koloni \\
\hline Aspergilus & $3,6 \times 10^{4}$ & \\
& & \\
\hline & & \\
\hline Phytium & $3,6 \times 10^{4}$ & \\
& & 6 \\
\hline
\end{tabular}

Dilihat dari keseluruhan populasi mikroorganisme rizosfer pada tanaman rambutan menunjukkan bahwa populasinya termasuk tidak banyak, hal ini menunjukkan bahwa kondisi tanah pada daerah tersebut diatas termasuk kurang subur, karena tanah pertanian yang subur mengandung lebih dari 100 juta mikroba per gram tanah. Rendahnya populasi bakteri ini disebabkan karena bakteri yang hidup di daerah rhizosfer harus berkompetisi dengan mikroba tanah yang lain untuk mendapatkan eksudat akar untuk kelangsungan hidupnya (Kirchhof et al., 1997; James et al., 2001). Dilaporkan oleh Gibson (1981) bahwa aktivitas metabolisme dan senyawa metabolit yang dilepaskan oleh tanaman melalui akar merupakan faktor yang sangat menentukan keadaan mikrobiologi tanah pada daerah perakaran. Apa bila dibandingkan antar jenis tana man populasinya sangat bervariasi. Adanya perbedaan populasi antar marga dan spesies tersebut mungkin disebabkan oleh aktivitas metabolisme akar dari masing-masing tanaman berbeda, yang menyebabkan perbedaan komposisi eksudat, yang akan menentukan populasi bakteri pada daerah perakaran. Hasil penelitian Stolassa dan Ernest dalam Waksman (1952) bahwa populasi bakteri pada daerah perakaran tanaman semuanya jauh lebih banyak dari pada tanaman biji-bijian. Satu gram tanah dari perakaran tanaman mengandung 7 sampai 8 juta bakteri, sedangkan pada tanaman barley mengandung 5 sampai 6 juta dan tanaman gula beets 1 sampai 2 juta. Penelitian Hoffman dalam Waksman (1952) bahwa 27 dari 32 
sampel tanah permukaan dan sekitar perakaran tanaman mempunyai populasi bakteri lebih banyak dibandingkan dengan tanah di dalam dan di luar perakaran. Sela in itu fakt or kesuburan tanah, kandungan $\mathrm{O}_{2}$, unsur hara, serta faktor fisik dan biologi tanah juga mempengaruhi populasi bakteri tanah.

Bakteri Azotobacter adalah species rizobakteri yang dikenal sebagai agen penambat nitrogen yang mengkonversi dinitrogen $\left(\mathrm{N}_{2}\right)$ ke dalam bentuk ammonium $\left(\mathrm{NH}_{3}\right)$, yang mampu menambat nitrogen dalam jumlah yang cukup tinggi. Pada medium yang sesuai, Azotobacter mampu menambat $10-20 \mathrm{mg}$ nitrogen/g gula (Wedhastri,2002). Azotobacter diketahui pula mampu mensintesis substansi yang secara biologis aktif dapat meningkatkan perkecambahan biji, tegakan dan pertumbuhan tanaman seperti vitamin B, asam indol asetat, giberelin, dan sitokinin (Wedhastri, 2002; Ahmad et al., 2005; Husen, 2003; Adiwiganda et al.,2006). Selain itu, Azotobacter juga memiliki kemampuan dalam metabolisme senyawa fenol, halogen, hidrokarbon, dan juga berbagai jenis pestisida (Munir, 2006).

Bakteri Azotobacter yang diaplikasikan pada tanah pertanian akan terus mempersubur tanah karena bakteri tersebut akan semakin banyak jumlahnya di dalam tanah dan terus bekerja memfiksasi nitrogen, dan menaikkan biomassa tanaman pertanian (Hindersah \& Simarmata, 2004). Fungsi Azotobacter untuk pertanian dan perkebunan menghasilkan hormon pertumbuhan dan mengurangi serangan hama. Bakteri dari famili Azotobacteraceae merupakan sebagian besar dari bakteri pemfiksasi nitrogen yang hidup bebas. Azotobacter yang diinokulasi dari tanah atau biji dengan Azotobacter efektif meningkatkan hasil tanaman budidaya pada tanah yang dipupuk dengan kandungan bahan organik yang cukup. Azotobacter juga diketahui mampu mensintesis substansi yang secara biologis aktif seperti vitamin-vitamin $\mathrm{B}$, asam indol asetat, dan giberelin dalam kultur murni. Organisme ini memiliki sifat dapat menghambat pertumbuhan jamur (fungistatik) bahkan jamur tertentu yang sangat patogen seperti Alternaria dan Fusarium. Sifat Azotobacter ini dapat menjelaskan pengaruh menguntungkan yang dapat diamati pada bakteri ini dalam meningkatkan tingkat perkecambahan biji, pertumbuhan tanaman, tegakan tanaman, dan pertumbuhan vegetatif. Beberapa eksperimen yang dilaksanakan di daerah beriklim sedang di dunia menunjukkan bahwa fiksasi nitrogen pada tanah yang diinokulasi dengan Azotobacter tidak akan lebih dari 10 sampai $15 \mathrm{~kg} \mathrm{~N} / \mathrm{ha} /$ tahun, tergantung tersedianya sumber karbon (Rao, 1986). Bakteri ini juga memiliki potensi mengekskresikan berbagai senyawa eksopolisakarida (EPS) dan asam lemak (Suryatmana et al., 2006). Eksopolisakarida dapat berfungsi sebagai biosurfaktan yang dapat meningkatkan biodegradasi limbah minyak bumi (Iwabuchi et al., 2002). Sedangkan Vater et al. (2002) menyatakan bahwa asam lemak berfungsi sebagai biosurfaktan karena merupakan senyawa amfifatik yang memiliki gugus liofobik dan liofilik. Sel Azotobacter berukuran besar dengan bentuk batang, banyak isolat hampir seukuran khamir, dengan diameter 2-4 $\mu \mathrm{m}$ atau lebih, biasanya polimorfik. Pada media yang mengandung karbohidrat, kapsul tambahan atau lapisan lendir diproduksi oleh bakteri pengikat nitrogen yang hidup bebas ini. Meskipun Azotobacter adalah bakteri aerob obligat, enzim nitrogenase yang dimilikinya yaitu enzim yang mengkatalisis pengikatan $\mathrm{N}_{2}$, bersifat sensitif terhadap $\mathrm{O}_{2}$. Sehingga diduga bahwa karakteristik Azotobacter yang mempunyai kapsul lendir yang tebal membantu melindungi enzim nitrogenase dari $\mathrm{O}_{2}$. Azotobacter dapat tumbuh pada berbagai macam jenis karbohidrat, alkohol, dan asam organik. Metabolisme senyawa karbon teroksidasi sempurna, sedangkan asam atau produk fermentasi yang lain jarang dihasilkan. Semua anggota dapat mengikat nitrogen tetapi pertumbuhan dapat juga terjadi pada media dengan senyawa nitrogen sederhana seperti amoniak, urea, dan nitrat. Azotobacter dapat membentuk struktur sel istirahat yang disebut kista. Seperti halnya bakteri berendospora, kista Azotobacter resisten terhadap proses pengeringan, penghancuran mekanik, ultraviolet, dan radiasi. Namun, tidak seperti endospora, kista Azotobacter tidak resisten terhadap panas dan tidak mengalami dormansi secara lengkap (Madigan et al., 2000). Azotobacter merupakan bakteri Gram negatif. Jenis azotobacter diantaranya Azotobacter chlorococcum dan Azotobacter vinelandi.

Aspergillus spp. (A. niger, A. fumigatus dan $A$. repens) telah dicoba secara in vitro, dapat menekan pertumbuhan jamur $P$. palmivora penyebab penyakit busuk buah kakao. Aspergillus terreus dapat menghambat pertumbuhan jamur patogen Botrytis cinerea karena mengeluarkan senyawa volatile seperti : $\alpha$-phellandrene, acetic acid pentyl ester dan 2acetyl-5-methylfuran (Ting et al., 2010). Aspergillus nidulans dapat bersifat antagonistik terhadap Colletotrichum gloeosporioides penyebab penyakit antraknose pada tanaman vanili. Hasil penelitian Fakhrunnisa et al. 
(2006) menemukan bahwa A. niger, A. flavus, A. terreus dan $A$. versicolor dapat menghambat pertumbuhan Fusarium spp. dengan membentuk zone hambatan secara in vitro. Bosah et al. (2010) juga telah menemukan bahwa Aspergillus spp. dapat menghambat pertumbuhan jamur patogen Sclerotium rolfsii dengan daya hambat sebesar $73,12-88,35 \%$. Proses penghambatan disebabkan karena Aspergillus spp. menghasilkan enzim chitinase dan $\beta-1,3$ glucanase (Laminarinase) yang mempunyai kemampuan untuk memecah komponen dinding sel jamur patogen seperti : chitin dan $\beta-1,3$ glucan. Kaewchai dan Soytong (2010) juga melaporkan penggunaan biofungisida yang mengandung lima jenis jamur, yaitu Aspergillus niger, Chaetomium bostrychodes, Ch. cupreum, T. hamatum, dan T. harzianum dapat menghambat perkembangan patogen $R$. microporus lebih dari $50 \%$.

Patogen tular tanah, antara lain Fusarium sp., Pythium sp., Sclerotium rolfsii, Phytophthora sp., dan R. solani. (Tondje et al. 2007). Jamur Phytium bersifat sebagai saprofit atau parasit tingkat rendah yang menyerang jaringan akar tanaman. Tanah sebagai media tempat tumbuh dan berkembangnya patogen tular tanah sebelum patogen tersebut menemukan inangnya sudah tentu akan berpengaru terhadap mikroorganisme tersebut baik dalam hal populasi atau reproduksi dan kelimpahannya, penyebarannya, daya tahannya dan patogenesitas serta virulensinya (Ownley et al, 2003). Sifat-sifat tanah yang berhubungan erat dengan pertumbuhan dan perkembangan patogen tular tanah antara lain adalah temperatur, tekstur tanah, kelembaban tanah, $\mathrm{pH}$ tanah, hara tanah serta keadaan bahan organik dalam tanah (LaMondia dan Cowles, 2005; Manici et al, 2005; Elhottova et al, 2006).

Umumnya perkembangan patogen tular tanah akan terhambat pada temperatur tanah yang ekstem tinggi, karenanya solarisasi tanah sering digunakan untuk membebaskan tanah dari berbagai patogen tular tanah. Pinkerton et al (2002), melaporkan bahwa dengan solarisai maka suhu tanah dapat meningkat dan menyebabkan kematian atau menurunnya populasi patogen tular tanah seperti Rhizoctonia $s p$ dan pythium $s p$. Tekstur tanah merupakan faktor penentu kesuburan dan kesehatan tanaman. Umumnya patogen tular tanah seperti Pythium sp. berkembang baik pada

\section{KESIMPULAN}

1. Hasil isolasi mikoorganisme rizosfer tanaman rambutan diperoleh 3 isolat. Hasil identifikasi tanah-tanah yang mempunyai kandungan debu dan liat tinggi karena pada tanah demikian biasanya drainasenya jelek sehingga mendukung perkembangan patogen ini (Wing et al, 1995). Dilaporkan oleh Barker dan Weeks (1991), bahwa reproduksi nematoda Pratilenchus penetrans meningkat pada tanahtanah bertekstur pasir sedangkan pada tanah berlempung reproduksinya rendah. Seperti halnya temperatur, kelembaban tanah juga berperan dalam perkembangan dan terjadinya penyakit oleh patogen tular tanah. Kelembaban umumnya berpengaruh terhadap daya kecambah spora patogen dan penetrasi inang oleh tabung kecambah. Kelembaban dalam bentuk air irigasi atau air yang mengalir juga berperan penting dalam distribusi dan penyebaran patogen. Serangan Pythium $s p$. penyebab rebah kecambah akan meningkat sebanding dengan peningkatan kelembaban tanah hingga mendekati titik jenuh (Agrios, 1997).

Keasaman atau $\mathrm{pH}$ tanah berperan penting dalam terjadinya dan keganasan pnyakit tanaman yang disebabkan oleh pati patogen tular tanah. Serangan Plasmodiophora brassicae akan terjadi sangat parah pada tanah dengan $\mathrm{pH}$ antara 5,7, sedangkan pada $\mathrm{pH}$ tanah 6,2 serangannya akan menurun dan tidak berkembang sama sekali pada ph 7,8 (Agrios, 1997). Penyaki lanas pada tembakau dapat terjadi pada tanah dengan $\mathrm{pH}$ asam maupun basa akan tetapi $\mathrm{pH}$ optimum bagi perkembangan $P$. nicotianae adalah 6-7 (Sullivan, 2005). Menurut Porth et al (2003), perkembangan patogen umumnya akan tertekan pada $\mathrm{pH}$ tinggi, karena pada $\mathrm{pH}$ tinggi akan mengakibatkan komdisi lingkungan tiak sesuai untuk perkembangan patogen tular tanah. Patogen umumnya akan lebih infektif pada keadaan $\mathrm{pH}$ tanah rendah (Campbell dan Greathead (1996). Kandungan unsur hara dalam tanah berhubungan erat dengan ketahanan tanaman terhadap patogen tanah demikian pula kandungan bahan organik dalam tanah. Bahan organik dapat membantu perkembangan mikroorganisme yang dapat menghambat aktivitas jamur patogen. Kolonisasi oleh Pythium sp. akan tinggi apabila kadar bahan organik tanah rendah (Manici et al, 2005). Penambahan bahan organik yang berkadar $\mathrm{N}$ tinggi dapat menekan perkembangan patogen tular tanah. terseleksi meliputi : 1 isolat bakteri dan 2 isolat jamur. 
2. Isolat bakteri teridentifikasi termasuk Famili Azotobacteraceae serta isolat jamur teridentifikasi termasuk genus Aspergilus dan genus Phytium.

3. Famili Azotobacteraceae berperan dalam penambatan (fiksasi) $\mathrm{N}_{2}$ dan Genus

\section{DAFTAR PUSTAKA}

Anindyawati, T. 2003. Mikrobia endofit: Manfaat dan cara mengisolasinya. Alam Kita. 12 (1): 11-14.

Belewu, M.W \& Musa, A.K. 2003. Effect of Selected Azotobacter Bacterial Strains on the Enrichment of Cassava Waste During Sold State Fermentation. Nigeria : University of Ilorin. Vol 6(1), 7 halaman.

Chanway, C.P. 1997. Inoculation of Tree Roots with Plant Growth Promoting Bacteria: An Emerging technology for reforestation. Forest Science 43: 96-112.

Hindersah, R \& T. Simarmata. 2004. Potensi Rizobakteri Azotobacter dalam Meningkatkan Kesehatan Tanah. Jurnal Natur Indonesia. 5, (2), 127-133.

Husen, E. 2003. Screening of Soil Bacteria for Plant Growth Promotion Activities In Vitro. Indonesian Journal of Agricultural science.4(1) 2003: 27-31.

Hyakumachi, $M$ and M Kubota. 2003. Fungi as plant growth promoter and disease suppressor. Pp. 101- 110 In: Fungal Biotechnology in Agricultural, Food and Environmental Application. Arora D. K. (ed) Marcel Dekker.

Karban, R. and Kuc. 1999. Induced resistance against pathogens and herbivores: An overview. Pp. 1-15 In Induced Plant Defenses Against Pathogens and Herbivores: Biochemistry, Ecology and Agriculture, (AA Agrawal, S Tuzun and E. Bent, eds.) APS Press, St. Paul, Minnesota.
Aspergillus merupakan jamur antagonis yang berpotensi untuk mengendalikan pathogen (penyakit) serta Genus Phytium merupakan jamur pathogen (penyebab penyakit).

Kristian Metasari. 2011. Eksplorasi Bakteri Penambat Nitrogen Non Simbiosis Dari Tanah Kawasan Mangrove Wonorejomen. Biologi, Fakultas Sains dan Teknologi, Universitas Airlangga, Surabaya.

Kaewchai, S. and K. Soytong. 2010. Application of Biofungicides Against Rigidoporus Microporus Causing White Root Disease of Rubber Trees. Journal of Agricultural Technology 6 (2): 349-363.

Meera, MS; MB Shivana; K Kageyama and M Hyakumachi, 1994. Plant Growth promoting fungi from Zoysiagrass Rhizosphere as Potential Inducers of Systemic Resistence in Cucumber. Phytopathology 84; 1399 - 1406.

Munir, E (2006). Pemanfaatan Mikroba dalam Bioremediasi: Suatu Teknologi Alternatif Untuk Pelestarian Lingkungan. Medan: Universitas Sumatera Utara.

Prihatman, K. 2000. Rambutan. warintek.ristekdikti.go.id.pertanian.

Tanaka, M. H. Sukiman, M. Takebayashi, K. Saito, M. Suto, M. S. Prana, and F. Tomita. 1999. Isolation, screening, and phylogenetic identification of endophytic plants in Hokaido Japan and Java Indonesia. Microbes and Environment. 14 (4): $237-241$.

Wedhastri, S. 2002. Isolasi dan seleksi Azotobacter spp.Penghasil Faktor Tumbuh dan Penambat Nitrogen dari Tanah Masam. Jurnal Ilmu Tanah dan Lingkungan . 3, (1), 45-51. 